\title{
Gibberellic acid in vegetative and reproductive development of Phalaenopsis orchid hybrid genus
}

\author{
Jean C Cardoso ${ }^{1}$; Elizabeth O Ono ${ }^{2}$; João D Rodrigues ${ }^{2}$ \\ 'USP-CENA, Dep. Biotecnologia Vegetal, C. Postal 96, 13416-000 Piracicaba-SP; jeancardosoctv@gmail.com; ${ }^{2}$ UNESP-IBB, Dep. \\ Botânica, 18603-970 Botucatu-SP; eoono@ibb.unesp.br
}

\begin{abstract}
The flower industry represents about one billion dollars in Brazil and the development of techniques aimed at flowering control is required. This study evaluated the influence of gibberellic acid $\left(\mathrm{GA}_{3}\right)$ on the vegetative and reproductive development of young plants of Phalaenopsis FSNT 'Dai-Itigo' hybrid pink color. The application of $\mathrm{GA}_{3}$ was made by foliar sprays at concentrations of $0,125,250$, 500 and $1,000 \mathrm{mg} \mathrm{L}^{-1}$. The length of leaves increased significantly when using $\mathrm{GA}_{3}$ at low concentrations, but leaf width decreased. The application of $\mathrm{GA}_{3}$ at $125 \mathrm{mg} \mathrm{L}^{-1}$ showed the best results for the promotion of flowering and flower quality of this orchid hybrid. In this treatment, about $50 \%$ of plants treated with $\mathrm{GA}_{3}$ flowered about 6-12 months before the plants that were non-treated with this plant growth regulator. The quality of flowering and flowers was best with $125 \mathrm{mg} \mathrm{L}^{-1} \mathrm{GA}_{3}$.
\end{abstract}

Keywords: Phalenopsis, young plants, leaf size, precocity, flowering, quality.

\section{RESUMO}

Desenvolvimento vegetativo e reprodutivo de orquídea híbrida do gênero Phalaenopsis tratadas com ácido giberélico

O setor de floricultura movimenta cerca de um bilhão de dólares no Brasil e o desenvolvimento de técnicas direcionadas ao controle do florescimento é necessário. O presente trabalho avaliou a influência do ácido giberélico $\left(\mathrm{GA}_{3}\right)$ no desenvolvimento vegetativo e reprodutivo de plantas jovens de Phalaenopsis FSNT 'Dai-Itigo', híbrido de coloração rósea. A aplicação do $\mathrm{GA}_{3}$ foi feita via pulverização foliar nas concentrações de $0,125,250,500$ e $1.000 \mathrm{mg} \mathrm{L}^{-1}$. O comprimento das folhas aumentou consideravelmente com o uso do $\mathrm{GA}_{3}$ em baixas concentrações, porém houve diminuição da largura foliar das plantas tratadas com esse fitorregulador. A aplicação do $\mathrm{GA}_{3}$ na concentração de $125 \mathrm{mg} \mathrm{L}^{-1}$ apresentou os melhores resultados para a promoção do florescimento e qualidade da floração deste híbrido de orquídea. Nesse tratamento, aproximadamente $50 \%$ das plantas pulverizadas apresentaram floração cerca de 6-12 meses antes da floração das plantas sem aplicação do fitorregulador. Em conclusão, a qualidade da floração e das flores foi melhor no tratamento com $125 \mathrm{mg} \mathrm{L}^{-1}$ de $\mathrm{GA}_{3}$.

Palavras-chave: Phalenopsis, plantas jovens, tamanho da folha, precocidade, florescimento, qualidade.

(Recebido para publicação em 3 de fevereiro de 2011; aceito em 4 de dezembro de 2011)

(Received on February 3, 2011; accepted on December 4, 2011)

$\mathrm{T}^{\mathrm{s}}$ he Orchidaceae family comprises more than 25,000 species and thousands of hybrids with different sizes, shapes and colors of flowers. The export of floricultural products in Brazil totalized US\$31.5 million in 2009, but the amount of imports in the sector (US\$20 million) is still high (Kyiuna et al., 2010). Although the orchids have only a small share of this total, the annual increase of over $100 \%$ in exports represents a high potential for the export market (Junqueira \& Peetz, 2008).

The increase in production and consumption of flowers has been stimulated by the reduction of production costs, with the development of research and technologies for ornamental and flower plants, like the work of determining nutritional requirements (Ludwig et al., 2008) and substrates
(Ludwig et al., 2010). However, there are few papers with effects of plant growth regulators in species used in floriculture.

A climatic similarity between Brazil and some Asian countries contributes to the cultivation of highly commercial and ornamental species that has its center of origin in Asia (Suttleworth et al., 1994). As example, Cymbidium, Dendrobium and Phalaenopsis genera, growth in a large part of the world and with great commercial value, not just for the beauty of its flowers, but also for its easy hybridization and breeding, variety of colors and the flowers durability, enabling marketing and transportation over long distances.

Gibberellins are plant hormones biochemically characterized as tetracyclic diterpenoid acids.
Gibberellins influence the stimulus to flowering in different ways, activating promoter genes in the meristem such as LEAFY (Blasquez et al., 1998), replacing the period of low temperatures required for the flowering of many species and increasing the $\mathrm{C} / \mathrm{N}$ ratio in leaves through the activation of hydrolytic enzymes (Kerbauy, 2008). Gibberellins applied exogenously promote the flowering induction and flower development in plants that normally require long days under the conditions of short days, however, the reverse does not occur, although there are exceptions (Cid, 2000).

The objective of this study was to evaluate the plant development, early flowering and the quality of flowering of Phalaenopsis orchids using different concentrations of gibberellic acid $\left(\mathrm{GA}_{3}\right)$ 
by foliar spraying.

\section{MATERIAL AND METHODS}

The experiment was conducted in Pompeia, São Paulo state, Brazil (22॰06'29'S, 50¹0’36”'W).

The plant material consisted of individual seedlings of a Phalaenopsis hybrid, pinkish in color, and obtained by in vitro seeding. The Phalaenopsis plants used were 'FSNT Dai-Itigo' that were acclimatized and grown for eight months in greenhouse conditions. We selected for this experiment those plants presenting similar size and growth characteristics, to form a homogenized plant group to receive the application of different concentrations of gibberellic acid $\left(\mathrm{GA}_{3}\right)$.

Plants were grown in greenhouse conditions with $70 \%$ shading associated with a layer of $30 \%$ Aluminet $^{\mathbb{R}}$. Irrigation was performed four times a week using micro-sprinklers, irrigating about 150 $\mathrm{mL}$ of water per plant. The fertilization was made four times weekly with $1 \mathrm{~g} \mathrm{~L}^{-1}$ of the formula $15-15-20$ and $20-10-10$, supplemented with $0.5 \% \mathrm{Mg}, 0.02 \% \mathrm{~B}$, $0.05 \% \mathrm{Cu}, 0.10 \% \mathrm{Mn}, 0.02 \% \mathrm{Mo}$ and $0.10 \% \mathrm{Zn}$, applied by drip irrigation. For the cultivation of the plants, we used transparent plastic pots $(1.3 \mathrm{~L}$ volume capacity) filled with coconut chips as substrate.

The treatments consisted of five concentrations of $\mathrm{GA}_{3}: 0,125,250$, 500 and $1,000 \mathrm{mg} \mathrm{L}^{-1}$, applied twice at intervals of 14 days under foliar spraying.

We used $\mathrm{GA}_{3}$ with at least $95 \%$ purity. The product was diluted in $4 \mathrm{~mL}$ of $92.8^{\circ} \mathrm{GL}$ hydrated ethyl alcohol with the addition of $1 \mathrm{~mL}$ of Tween $20{ }^{\circ}$ per solution liter $(0.1 \%)$ before completing the solution with water. Control plants were treated with water containing $0.1 \%$ Tween $20^{\circ}$.

The spraying was done between the dates of November 10 and December 10, 2006, in the morning (between 7 and 8 a.m.), when the air humidity is highest in the region, favouring the absorption of the product. For the spraying a $20 \mathrm{~L}$ costal sprayer $\left(\right.$ Jacto $^{\odot}$ ) coupled with an $\mathrm{X} 2$ conical type nozzle was used. Upon application, the plants treated with the spray were separated from each other to prevent contamination with the product. Each plant was sprayed with about 40 $\mathrm{mL}$ of solution, directing the jet to the adaxial side of leaves, with runoff of the product to the roots.

The experimental design was of completely randomized blocks with six plants (replicates) for each treatment. The experiment lasted 12 months and was repeated twice.

The size of the plants was obtained through the width and the length of the leaves obtained after the treatment with different concentrations of $\mathrm{GA}_{3}$. The reproductive phase was evaluated by the flowering quality, such as the time of the first flowering, flowering rate (\%), the length of inflorescence, the number of flowers and the quality of the flowers obtained in each treatment. The quality of flowers was measured by the diameter of flowers and petals of flowering plants.

The flowering rates $(\%)$ were converted to $\arcsin \sqrt{x+0.5}$. All data were analyzed by ANOVA and the means were compared using the Duncan's multiple range test at $5 \%$ of probability. Linear regression was performed to establish the correlation between leaf length and the rate of flowering (\%).

\section{RESULTS AND DISCUSSION}

Concerning the plant growth, there was influence of the $\mathrm{GA}_{3}$ concentrations on the size of the leaves of Phalaenopsis 'FSNT Dai-Itigo'. The increase was from $10.9 \mathrm{~cm}$ (control) to $18.1 \mathrm{~cm}$ in a treatment using $125 \mathrm{mg} / \mathrm{L}$ (Table 1). In relation to the best treatment $(125$ $\mathrm{mg} \mathrm{L}^{-1}$ of $\mathrm{GA}_{3}$ ), the higher doses of $\mathrm{GA}_{3}$ showed a slight decrease in the length of the leaves by increasing the concentrations used. The width of the leaves was reduced with the increased use of concentrations of $\mathrm{GA}_{3}$, falling from $5.7 \mathrm{~cm}$ (control) to $4.4 \mathrm{~cm}$ with the use of $500 \mathrm{mg} \mathrm{L}^{-1}$ of $\mathrm{GA}_{3}$ applied by foliar spray on the young plants of Phalaenopsis (Table 1).

The increase in length of the leaves of young Phalaenopsis plants, with age of 12 months, visually resembled plants with higher age, adult and ready to flowering (Figure 1). The results obtained for the leaf length and diameter for this species are consistent with those obtained by Vichiato et al. (2007) in Dendrobium nobile orchids. The cell growth promoted by the gibberellins, through the activation of hydrolytic enzymes, increases the length of the cells compared to their diameter, making tissues and organs such as leaves, stems and fruits, longer and thinner (Taiz \& Zeiger, 2009).

An increase in the percentage of flowering plants and the quality of blooming with the use of $\mathrm{GA}_{3}$ was also observed and this could be used to accelerate the flowering of Phalaenopsis. With the application of $125 \mathrm{mg} \mathrm{L}^{-1}$ of $\mathrm{GA}_{3}, 50 \%$ of the plants of Phalaenopsis, at 12 months of age, flourished in their flowering season (May/June), about 4-6 months before the plants not treated with this plant growth regulator and 6 to 12 months before the commercial flowering of this orchid, demonstrating the effect of $\mathrm{GA}_{3}$ in early flowering and shortening the juvenility of this genus of orchids. The use of concentrations higher than $125 \mathrm{mg} \mathrm{L}^{-1}$ of $\mathrm{GA}_{3}$ did not increase the percentage of flowering, and under these conditions only $33 \%$ of plants flowered in the same period. In the control, the percentage of flowering plants was $16.7 \%$. This may be due to the fact that these concentrations may be above those required for the flowering of this hybrid of Phalaenopsis (Table 1).

The physiological effects of some gibberellins in flowering were observed and depend on the plant species or cultivar. The responses could be positive, neutral or negative in the induction of flowering; generally the response of the induction of flowering by GAs occur more frequently in longday plants (LDP) and plants which require a period of low temperature (vernalization) to blooming (Kerbauy, 2008). The latter seems to be the case for most of the Phalaenopsis species, since the use of low temperatures, regardless of photoperiod, appears to be a limiting factor for the flowering of these plants, a technique used in commercial productions.

According to Wang (2000), species 
Table 1. Vegetative and reproductive development of Phalaenopsis 'Dai-Itigo' sprayed with gibberellic acid (desenvolvimento vegetativo e reprodutivo de Phalaenopsis 'Dai-Itigo’ pulverizados com diferentes concentrações de ácido giberélico). Pompéia. FSNT. 2006.

\begin{tabular}{|c|c|c|c|c|c|c|c|}
\hline \multirow{2}{*}{ Development } & & \multicolumn{5}{|c|}{ Concentrations of $\mathrm{GA}_{3}\left(\mathrm{mg} \mathrm{L}^{-1}\right)$} & \multirow{2}{*}{ CV $(\%)$} \\
\hline & & Control & 125 & 250 & 500 & 1.000 & \\
\hline \multicolumn{8}{|l|}{ Vegetative parts } \\
\hline \multirow{2}{*}{ Leaves $(\mathrm{cm})$} & Lenght & $10.9 \mathrm{c}$ & $18.1 \mathrm{a}$ & $17.0 \mathrm{a}$ & $14.3 \mathrm{~b}$ & $16.2 \mathrm{ab}$ & 9.72 \\
\hline & Width & $5.7 \mathrm{a}$ & $5.8 \mathrm{a}$ & $4.9 \mathrm{ab}$ & $4.4 \mathrm{~b}$ & $4.9 \mathrm{ab}$ & 14.33 \\
\hline \multicolumn{8}{|l|}{ Reproductive parts } \\
\hline Flowering rate $(\%)$ & & $16.7 \mathrm{~b}$ & $50.0 \mathrm{a}$ & $33.3 \mathrm{ab}$ & $33.3 \mathrm{ab}$ & $33.3 \mathrm{ab}$ & 27.38 \\
\hline \multirow[t]{2}{*}{ Inflorescence } & Lenght $(\mathrm{cm})$ & 20.1 & 45.5 & 47.0 & 38.8 & 45.0 & ns \\
\hline & Number of flowers & 3.0 & 6.6 & 6.5 & 5.0 & 6.0 & ns \\
\hline \multirow[t]{2}{*}{ Diameter $(\mathrm{cm})$} & Flowers & 8.5 & 9.4 & 8.7 & 7.7 & 8.6 & $\mathrm{~ns}$ \\
\hline & Petals & 5.5 & 5.8 & 5.4 & 5.2 & 5.5 & ns \\
\hline
\end{tabular}

*Means followed by the same letter in the line do not differ by Duncan's multiple range test at 5\% of probability; Ns= non-significant (medias seguidas pela mesma letra não diferem entre si pelo teste de Duncan a 5\% de probabilidade; ns= não significativo).

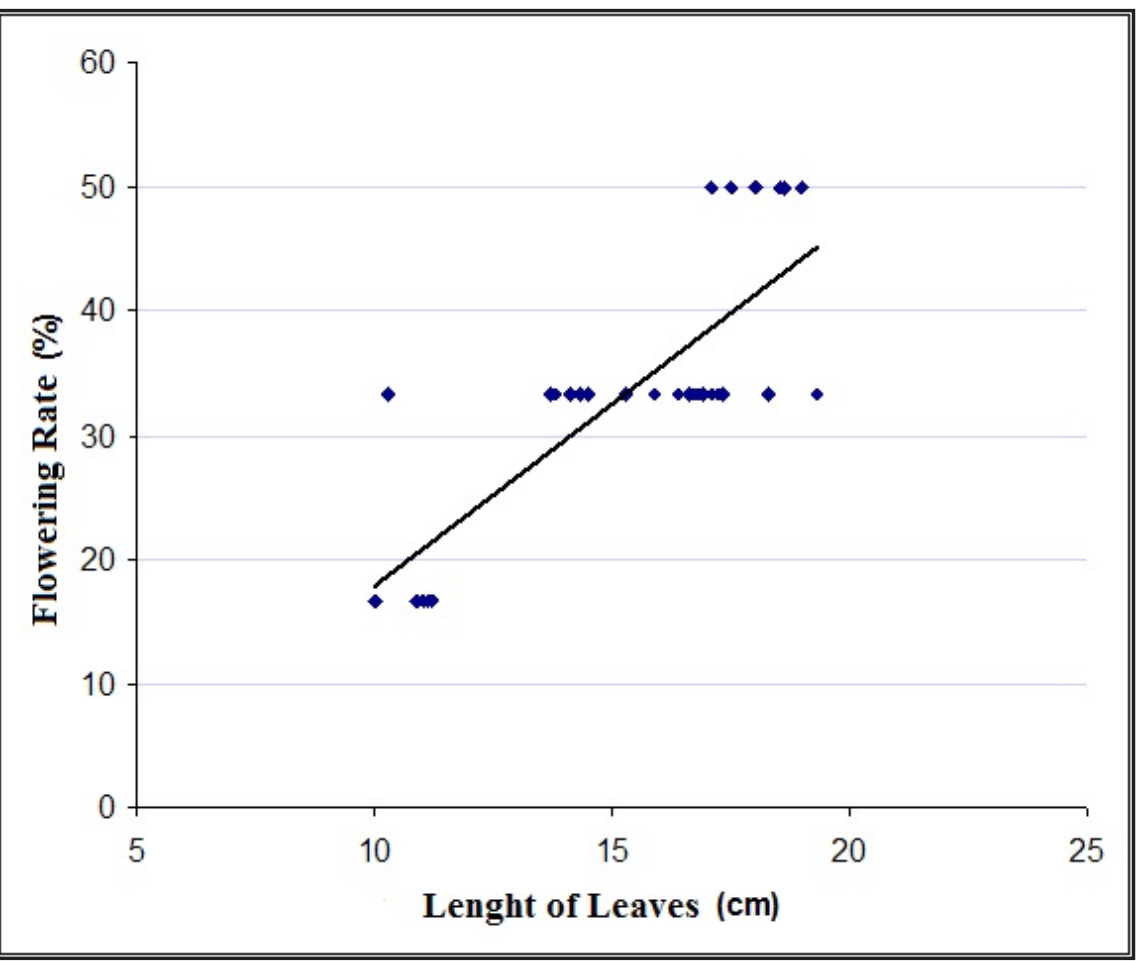

Figure 1. Correlation between the leaf length $(\mathrm{cm})$ and the flowering rate $(\%)$ of plants of Phalaenopsis 'Dai-Itigo' with 12 months of age and sprayed with different concentrations of $\mathrm{GA}_{3}$ (correlação entre o comprimento das folhas $(\mathrm{cm})$ e a taxa de florescimento $(\%)$ de plantas de Phalaenopsis 'Dai-Itigo' com 12 meses de idade e pulverizadas com concentrações de $\mathrm{GA}_{3}$ ). Pompéia, FSNT, 2006. $\mathrm{Y}=2.92 \mathrm{x}-11.31, \mathrm{R}^{2}=0.64 *$

and hybrids of Phalaenopsis require a period of 3-5 weeks of exposure to a reduction of temperature from 25 to $15^{\circ} \mathrm{C}$ to initiate the induction of flowering.

Kataoka et al. (2004) observed a significant increase in the amount of sucrose in the leaves of pre-flowering Phalaenopsis when these were grown in results on the induction of flowering of Phalaenopsis 'Leda'.

A positive correlation $\left(r=0.64^{*}\right)$ between the length of the leaves and the rate of flowering of Phalaenopsis 'FSNT Dai-Itigo' (Figure 1) was observed. This result and the fact that plants thrive in their normal flowering season led to the proposal of an indirect effect of $\mathrm{GA}_{3}$ on flowering induction, caused by increasing the size of Phalaenopsis leaves with $\mathrm{GA}_{3}$. High quantities of energy are necessary for flowering induction and development of the flowers. The number and size of leaves increase the photosynthetic area, ledding to high energy production, and that sustain the development of inflorescences and flowers (Bustan \& Goldschmidt, 1998; Taiz \& Zeiger, 2009).

The number of inflorescences was the same in all plants observed, one inflorescence per plant. However, an increase in the length of the flower stalks, from 20 to $45.3 \mathrm{~cm}$, was observed using the treatment with $125 \mathrm{mg} \mathrm{L}^{-1} \mathrm{GA}_{3}$ compared to control plants sprayed with water. The number of flowers per plant also increased to 6.6 at a concentration of $125 \mathrm{mg} \mathrm{L}^{-1} \mathrm{GA}_{3}$, compared to 3.0 flowers per plant in those treated with water (Table 1). The length of the inflorescence and the number of flowers have been used as parameters to evaluate the quality of classification of Phalaenopsis plants in flower markets, where long inflorescences 
and a high number of flowers get the best classifications and prices (Veilling, 2009).

The flower quality was also affected by the application of different concentrations of $\mathrm{GA}_{3}$ (Table 1). The best result on the diameter of the flowers also was obtained using $125 \mathrm{mg} \mathrm{L}^{-1} \mathrm{GA}_{3}$. The application of this plant growth regulator in this concentration allowed the flowers obtained to a diameter about $0.9 \mathrm{~cm}$ larger than the flowers obtained in control plants. Still, the increase in the diameter of the petals creates a visual appearance having good impact, increasing the quality of the flowers. The fact that higher concentrations of $\mathrm{GA}_{3}$ promoted reduction in the size of the flowers and the diameter of the petals may be explained due to the phytotoxicity of $\mathrm{GA}_{3}$ applied in high concentrations. The absence of statistical differences on these data is mainly due to the great number of zero values, attributed to the failure of flowering of some plants.

The results obtained in this experiment were according with Chen et al. (2003) that also observed an increase in the quality of the flowering plants of Philodendron 'Black Cardinal' by applying $\mathrm{GA}_{3}$ compared to those treated with water.

The experiment achieved good results for the use of $\mathrm{GA}_{3}$ in the commercial production of Phalaenopsis, reducing the time for the first flowering to 6-12 months and increasing the quality of first flowering, which in normal cultivation conditions and without the application of this plant growth regulator, is generally of poor quality, with few flowers and short inflorescence, that results in noncommercial plants. It was possible to obtain approximately $50 \%$ of flowering induction of Phalaenopsis plants at 12 months of age, averaging 6.6 flowers per plant, with a $\mathrm{GA}_{3}$ application at $125 \mathrm{mg} \mathrm{L}^{-1}$ reducing the time of the first flowering for fast marketing of the product. At this concentration, the $\mathrm{GA}_{3}$ also promoted an increase in inflorescence length and diameter of flowers and petals, improving the quality of flowering.

\section{ACKNOWLEDGEMENTS}

To Ph Ds Elizabeth Orika Ono and João Domingos Rodrigues for their help in the experimental phases and to Ph Ds Carmen SF Boaro, Armando $\mathrm{R}$ Tavares and Norberto Silva for valuable informations for this paper. To 'Fundação Shunji Nishimura de Tecnologia', specially to Mr. Shunji Nishimura, for financial and structural support for this research.

\section{REFERENCES}

BLÁSQUEZ MA; GREEN R; NILSSON O; SUSSMAN MR; WEIGEL D. 1998. Gibberellins promote flowering of Arabidopsis by activating the LEAFY promoter. The Plant Cell 10: 791-800.

BUSTAN A; GOLDSCHMIDT EE. 1998. Estimating the cost of flowering in a grapefruit tree. Plant and Cell Environment 21:217-224.

CHEN WS; CHANG HW; CHEN WH; LIN YS. 1997. Gibberellic acid and cytokinin affect Phalaenopsis flower morphology at high temperature. Hortscience 32: 1069-1073.

CHEN J; HENNY RJ; MCCONNELL DB;
CALDWELL RD. 2003. Gibberellic Acid affects growth and flowering of Philodendron 'Black Cardinal'. Plant Growth Regulation 41: 1-6.

CID LPB. 2000. Introdução aos hormônios vegetais. Brasília: EMBRAPA Recursos Genéticos e Biotecnologia. 180p.

JUNQUEIRA AH; PEETZ MS. 2008. Análise conjuntural das exportações de flores e plantas ornamentais do Brasil. Disponível em www. portaldoagronegócio.com.br. Acessado em maio de 2009.

KATAOKA K; SUMITOMO K; FUDANO T; KAWASE K. 2004. Changes in sugar content of Phalaenopsis leaves before floral transition. Scientia Horticulturae 102: 121-132.

KERBAUY GB. 2008. Fisiologia Vegetal. Rio de Janeiro: Ed. Guanabara Koogan Ltda. 431p.

KIYUNA I; ANGELO JA; COELHO PJ. 2010. Comércio exterior da floricultura brasileira em 2009: ponto de inflexão. Análises e Indicadores do Agronegócio 5. Disponível em http://www.iea.sp.gov.br/out/verTexto. php?codTexto=11881. Acesso em junho de 2010.

LUDWIG F; FERNANDES DM; MOTA PRD; VILLAS BÔAS RL. 2008. Macronutrientes em cultivares de gérbera sob dois níveis de fertirrigação. Horticultura Brasileira 26: 68-73.

LUDWIG F; GUERRERO AC; FERNANDES DM; VILLAS BÔAS RL. 2010. Análise de crescimento de gérbera de vaso conduzida em diferentes substratos. Horticultura Brasileira 28: 70-74.

SUTTLEWORTH FS; ZIM HS; DILLON GW. 1994. Orquídeas: Guia dos orquidófilos. Rio de Janeiro: Ed. Expressão e Cultura. 158 p.

TAIZ L; ZEIGER E. 2009. Fisiologia Vegetal. Porto Alegre: Artmed. 719p.

VEILLING. 2009. Catálogo Veilling 2007. Disponível em: http://www.veiling.com.br/ produtos/Vaso-5.pdf. Acessado em maio de 2009.

VICHIATO MVM; VICHIATO M; DE CASTRO DM; DUTRA LF; PASQUAL M. 2007. Alongamento de plantas de Dendrobium nobile Lindl. Com pulverização de ácido giberélico. Ciência e Agrotecnologia 31: 16-20.

WANG YT. 2000. Phalaenopsis orchid light requirement during the induction of spiking. Hortscience 30: 59-61. 